\title{
The Effects of Cadmium on Microsomal Drug Metabolizing Enzyme System in Rat Livers
}

\author{
Masaru Sagai, Fujio Shiraishi and Kentaro Kubota \\ Division of Basic Medical Sciences, The National Institute for Environmental Studies, \\ Yatabe, Ibaraki
}

\section{SUMMARY}

Cadmium chloride administered intraperitoneally to rats caused a mainly dose-dependent decrease of microsomal protein and the cytochrome P-450 contents in the hepatic microsomal drug-metabolizing enzyme system. This dose-dependent decrease of cytochrome $b_{5}$ was slight. The concentrations of cadmium that decreased the activity of this system show no effect on sGOT and sGPT activity in this experiment.

Cadmium added in vitro caused the denaturation of cytochrome $\mathrm{P}-450$ to cytochrome $\mathrm{P}-420$, and the denaturation was dependent on the concentration of cadmium.

Experiments on the effect of cadmium on the activity of aminopyrine demethylase and aniline hydroxylase dependent cytochrome $\mathrm{P}-450$ were conducted in vivo and in vitro. The specific activity of the former was decreased more remarkably than that of the latter by cadmium administered in vivo. On the other hand, in in vitro experiment, aniline hydroxylase was inhibited much more than aminopyrine demethylase.

Enzyme kinetics to determine the inhibitory mechanism of aminopyrine demethylase and aniline hydroxylase were also conducted.

These results may indicate that the decrease of drug-metabolizing enzyme activity is mainly due to the denaturation of cytochrome P-450 rather than the inhibition of the terminal oxidase by cadmium.

\section{INTRODUCTION}

Cadmium compounds are well known to be toxic for men and aminals. Cadmium absorption, accumulation, excretion, biological halftime and binding to metallothionein has been studied widely by many workers and reviewed by Fribery et al. ${ }^{1)}$

It is known that the metabolic abnormalities induced by cadmium are observed in liver, kidney, testes and lung ${ }^{2,3)}$. However, there are but few studies regarding the effect of cadmium on the drug-metabolizing enzyme system. The microsomal drug-metabolizing enzyme system are responsible for metabolizing foreign compounds such as drug or environmental pollutants ${ }^{4,5)}$. Unger and Clausen ${ }^{6)}$ reported the inhibitory effect of cadmium on the cytochrome P-450 dependent p-nitroanisole demethylating activity. Pence et al., ${ }^{7)}$ reported that the hepatic microsomal metabolism of hexobarbital was significantly decreased in male rats after cadmium administration.

The present work was designed to discover the mechanism of harmful effect of cadmium on the cytochrome $\mathrm{P}-450$ and cytochrome $b_{5}$ linked drug-metabolizing enzyme system in rat liver.

\section{MATERIALS AND METHODS}

Chemicals. Aminopyrine (Sanko Kogyo Co. Ltd.,) and aniline hydrochloride (Wako Pure 
Chem. Co. Ltd.,) were recristalized from water. NADP and Glucose-6-phosphate dehydrogenase (G-6-PD) were purchased from Oriental Yeast Co. Ltd., Glucose-6-phosphate disodium salt (G-6-P) from Sigma Chemical Co. Ltd.. Other chemicals were obtained from Wako Pure Chemical Co. Ltd., in the purest grade.

Animals. Wistar-JCL male rats weighing $240 \mathrm{~g}$ to $290 \mathrm{~g}$ were used. Thirty eight rats were divided into four injected groups that received, respectively, $0.0,0.23,0.32$, and $0.45 \mathrm{mg}$ $\mathrm{Cd}^{2+}$ per $\mathrm{kg}$ of body weight at every injection, and the group contained $11,7,7$, and 13 rats, respectively. Cadmium was injected intraperitoneally as $\mathrm{CdCl}_{2}$ in $0.9 \%$ sterile saline. Injections were repeated eight times during the period of eleven days; the injection was avoided at the fourth, fifth and ninth day. Twenty-eight days after the initial cadmium injection, the animals were killed by removing blood from the carotid arteries under light anesthesia with ethyl ether.

Preparation of microsomes. Liver microsomes were prepared by the method of Omura and $\mathrm{Sato}^{8)}$. The microsomes were washed twice with $1.15 \% \mathrm{KCl}$, and the final precipitate by ultracentrifugation at $105,000 \times \mathrm{g}$ was placed in an ice bath overnight.

Then, the precipitate was suspended in $1.15 \% \mathrm{KCl}$ to give a protein concentration of $8 \mathrm{mg}$ per $\mathrm{m} l$.

Determination of cytochrome $P-450$ and $b_{5}$. The amounts of cytochromes in microsomes were determined by the modified method of Omura and Sato ${ }^{8}$. The difference in spectra of the cytochromes were measured in HITACHI 356 spectrophotometer. The difference in spectra of cytochrome P-450 was induced by the addition of carbon monoxide (CO) after reduction of cytochrome $\mathrm{P}-450$ in microsomes with sodium dithionite, and that of cytochrome $\mathrm{b}_{5}$ was induced by the reduction with the same chemical.

Sodium dithionite was used as $0.28 \mathrm{M}$ solution on $0.1 \mathrm{M}$ phosphate buffer which was dissolved with equal weight of potassium bicarbonate, and $\mathrm{CO}$ added as $0.1 \mathrm{M}$ phosphtate buffer saturated with $\mathrm{CO}$ gas.

$0.2 \mathrm{~m} l$ of sodium dithionite solution and $\mathrm{CO}$ solution were added to $2.5 \mathrm{~m} l$ of the diluted microsomes for the determination of cytochrome contents. These solutions were prepared freshly shortly before using. This modified method was efficient for measurement of cytochrome contents because it was compared with the original method of Omura and Sato ${ }^{8}$. The coefficient (extinction difference) used for the caluculation of cytochrome $\mathrm{P}-450$ contents was 0.091 at $450 \mathrm{~nm}$ and $490 \mathrm{~nm}$, and for cytochrome $b_{5}$ was 0.171 at $424 \mathrm{~nm}$ and $500 \mathrm{~nm}$.

Assay of drug metabolizing enzyme activities. Aminopyrine demethylase activities were determined at $37^{\circ} \mathrm{C}$ in a medium containing $0.25 \mathrm{M}$ phosphate buffer, $\mathrm{pH} 7.4 ; 6.6 \mathrm{mM}$ semicarbazide (for preventing from further oxidation of formed products), $4 \mathrm{mM} \mathrm{MgCl}, 0.16 \mathrm{mM}$ NADP, $1.66 \mathrm{mM}$ G-6-P, 5 units of G-6-PD, $1.6 \mathrm{mg}$ protein of microsomes, and $0.8 \mathrm{mM}$ aminopyrine in a final volume of $6 \mathrm{ml}$. In the in vitro assay, Tris- $\mathrm{HCl}$ buffer and $0.8 \mathrm{mM} \mathrm{NADPH}$ were used in compensation for phosphate buffer and NADPH regenerating system, respectively.

After preincubation for $5 \mathrm{~min}$, at $37^{\circ} \mathrm{C}$, the reaction was started by the addition of G-6-PD. The reaction was stopped by the addition of $2 \mathrm{~m} l$ each of $15 \% \mathrm{ZnSO}_{4}$ and saturated $\mathrm{Ba}(\mathrm{OH})_{2}$ solution after $30 \mathrm{~min}$, incubation period at $37^{\circ} \mathrm{C}$.

Formaldehyde formed by the demethylation reaction was determined according to the method of $\mathrm{Nash}^{9)}$. Aniline hydroxylase activities were determined at $37^{\circ} \mathrm{C}$ in a medium containing $60 \mathrm{mM}$ phosphate buffer, $\mathrm{pH} 7.4,5 \mathrm{mM} \mathrm{MgCl}, 0.2 \mathrm{mM}$ NADP, $2 \mathrm{mM} \mathrm{G-6-P,} 5$ units of G-6-PD, $1.6 \mathrm{mg}$ protein of microsomes, and $1 \mathrm{mM}$ aniline in a final volume of $5 \mathrm{~m} l$. In the in vitro assay, Tris- $\mathrm{HCl}$ buffer and $1 \mathrm{mM} \mathrm{NADPH}$ were used in compensation for phosphate buffer and NADPH regenerating system, respectively. 
After preincubation for $5 \mathrm{~min}$, at $37^{\circ} \mathrm{C}$, the reaction was started by the addition of G-6-PD. The reaction was stopped by the addition $2 \mathrm{ml}$ of $23.5 \%$ trichloroacetic acid solution after $30 \mathrm{~min}$, incubation period at $37^{\circ} \mathrm{C}$. p-Aminophenol formed was determined by the method of Imai et al. ${ }^{10)}$.

Assay of protein. Protein was measured by the Lowry method ${ }^{11)}$ using bovine serum albumin as a standard.

Determination of Metal contents. Metals were measured by using HITACHI 508-atomic absorbance spectrophotometer. Decomposition of organic materials in liver was accomplished by heating in nitric acid and perchloric acid mixture $(4: 1)$, and extraction of metals accomplished by DDTC extract method ${ }^{12)}$.

Statistical analysis. The data was analyzed throughout using the Student's $t$ teste, with p 0.05 as the level of significance.

\section{RESULTS}

Table 1 shows the conditions of the animals used in this experiment. Body weight, liver wet weight and microsomal protein per $g$ of liver wet weight of rats administered cadmium were decreased. Liver wet weight per $\mathrm{g}$ of body weight however did not differ from the control. The decrement of microsomal protein may indicate the destruction of endplasmic reticulum. The four rats in the group administered $0.45 \mathrm{mg} \mathrm{Cd}^{2+} / \mathrm{kg}$ died after the final cadmium administration.

Table 2 shows cadmium contents in liver and its subcellular fractions. Cadmium contents in the microsomal fraction was $1.46 \mathrm{ppm}$ to $3.29 \mathrm{ppm}$ and they corresponded to about $6 \%$ of

Table 1 The Effect of Cadmium on the Condition of Rats

\begin{tabular}{c|c|c|c|c|c}
\hline $\begin{array}{c}\text { Administered } \\
\text { Cd. conc. } \\
\text { mg/kg, B.W. }\end{array}$ & $\begin{array}{c}\text { number of } \\
\text { animals }\end{array}$ & $\begin{array}{c}\text { Body weight } \\
(\mathrm{g})^{\mathrm{a}}\end{array}$ & $\begin{array}{c}\text { Liver wet } \\
\text { weight }(\mathrm{g})^{\mathrm{a}}\end{array}$ & $\begin{array}{c}\text { Liver wet weight } \\
/ \text { Body weight } \\
(\mathrm{g} / \mathrm{g})^{\mathrm{b}}\end{array}$ & $\begin{array}{c}\text { Microsome protein/ } \\
\text { Liver wet weight } \\
\text { w/g)c }\end{array}$ \\
\hline 0.00 & 11 & $379.6 \pm 8.2$ & $15.94 \pm 0.36$ & 0.042 & $0.023(100)$ \\
0.23 & 7 & $356.7 \pm 8.1$ & $14.84 \pm 0.68$ & 0.042 & $0.022(96)$ \\
0.32 & 7 & $353.9 \pm 14.5$ & $14.88 \pm 0.56$ & 0.042 & $0.019(83)$ \\
0.45 & 9 & $320.1 \pm 8.5$ & $14.36 \pm 0.56$ & 0.045 & $0.015(65)$ \\
\hline
\end{tabular}

a: Values expressed as means $\pm \mathrm{SE}$

b: The values were expressed by the ratio between the means of liver wet weight and the means of body weight

c: The values expressed by the ratio between the dry weight of the pooled microsome protein and the means of liver wet weight

Table 2 Cadmium Contents in Liver and Its Subcellular Fractions

\begin{tabular}{c|c|c|c}
\hline \multirow{2}{*}{$\begin{array}{c}\text { Administered } \\
\text { Cd. dose } \\
\text { mg/kg B.W. }\end{array}$} & Whole Liver & $\begin{array}{c}\text { Cadmium Contents }(\mu \mathrm{g} / \mathrm{g} \text { wet weight of liver })^{\mathrm{a}} \\
\text { Supernatant Fraction }\end{array}$ & Microsome Fraction $^{\text {1000 } \times \mathrm{g}}$ \\
\hline 0.00 & 0.07 & 0.03 & 0.03 \\
0.23 & 23.1 & 20.1 & 1.46 \\
0.32 & 32.6 & 29.2 & 1.84 \\
0.45 & 50.4 & 44.0 & 3.29 \\
\hline
\end{tabular}

a: The specimens of equal wet weight, which was obtained from all samples, and pooled, was used or fractionized

b: Supernatant fraction was prepared by the ultracentrifigation of $105,000 \times \mathrm{g}$ for $60 \mathrm{~min}$ 


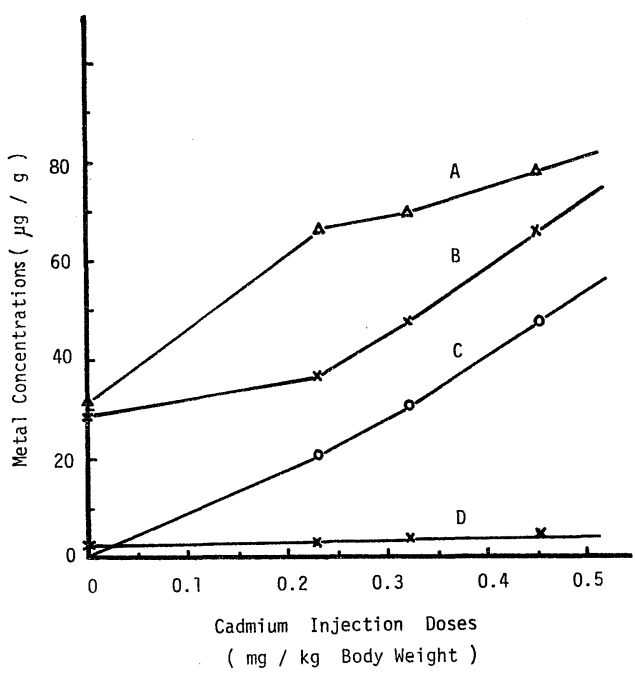

Fig. 1 The relationship between cadmium injection doses and metal concentrations in rat livers. Ferric ion (A), Zinc ion (B), Cadmium ion (C) and Cupper ion (D)

that of whole liver, respectively.

Fig. 1 indicates the some metal contents in liver as a function of the dosed cadmium. Cadmium administration caused the increment of zinc and ferric ion in liver, while cupper content was not changed.

Table 3 shows the effect of cadmium administration on the amounts of hepatic microsomal cytochrome P-450 and $b_{5}$. The amounts of cytochrome P-450 were remarkably decreased by cadmium administration. The mean value of the rats administered $0.45 \mathrm{mg} \mathrm{Cd}{ }^{2+} / \mathrm{kg}$ was $0.973 \mathrm{nmole} / \mathrm{mg}$ protein, corresponding to $67 \%$

Table 3 Effect of Cadmium on the Contents of Cytochrome P-450 and $b_{5}$ in Liver Microsomes

\begin{tabular}{c|cc|crc}
\hline $\begin{array}{c}\text { Cd } \\
\text { Administered } \\
\mathrm{mg} / \mathrm{kg}, \mathrm{B} . \mathrm{W} .\end{array}$ & $\begin{array}{c}\text { Cytochrome P-450 } \\
\text { contents }\end{array}$ & \multicolumn{2}{|c}{$\begin{array}{c}\text { Cytochrome } \mathrm{b}_{5}{ }^{a} \\
\text { contents }\end{array}$} & $\%$ \\
0.00 & $1.461+0.070$ & 100 & $0.930+0.021$ & 100 \\
0.23 & $1.197+0.160^{\mathrm{b}}$ & 82 & $0.825+0.052^{\mathrm{b}}$ & 89 & 84 \\
0.32 & $1.010+0.098^{\mathrm{c}}$ & 69 & $0.780+0.017^{\mathrm{c}}$ & 84 \\
0.45 & $0.973+0.065^{\mathrm{c}}$ & 67 & $0.795+0.038^{\mathrm{c}}$ & 85 \\
\hline
\end{tabular}

a: Cytochrome P-450 and $b_{5}$ contents are expressed as nanomole per mg protein. Values expressed as means $\pm \mathrm{SE}$.

b: Not significantly different from control group as judged by Student's $t$ test

c: $\mathrm{p}<0.01$ 
of the control value. On the other hand, the decrement of cytochrome $b_{5}$ content in hepatic microsomes from cadmium-treated rats was slight as shown in Table 3. These results indicate the possibility that cadmium inhibited the synthesis of two cytochromes or destroied two cytochromes. Furthermore, it was found that cytochrome P-450 is more sensitive to cadmium than cytochrome $b_{5}$.

The specific activity of aminopyrine demethylation and aniline hydroxylation dependent cytochrome P-450 was determined by cadmium administration (Table 4).

The specific activity of aminopyrine demethylation in the rats administered $0.45 \mathrm{mg} \mathrm{Cd}^{2+} / \mathrm{kg}$

Table 4 The Effects of Aminopyrine Demethylase and Aniline Hydroxylase in Rat Liver Microsomes

\begin{tabular}{c|c|c}
\hline \multirow{2}{*}{$\begin{array}{c}\text { Cd } \\
\text { Administered } \\
\text { mg/kg, B.W. }\end{array}$} & \multicolumn{2}{|c}{ Aminopyrine Demethylase } \\
\cline { 2 - 3 } 0.00 & nmole $\mathrm{HCHO} / \mathrm{min} / \mathrm{mg}$ protein & nmole HCHO/min/mg protein \\
/nmole P-450
\end{tabular}

a: $\mathrm{p}<0.001$

b: $\mathrm{p}<0.05$

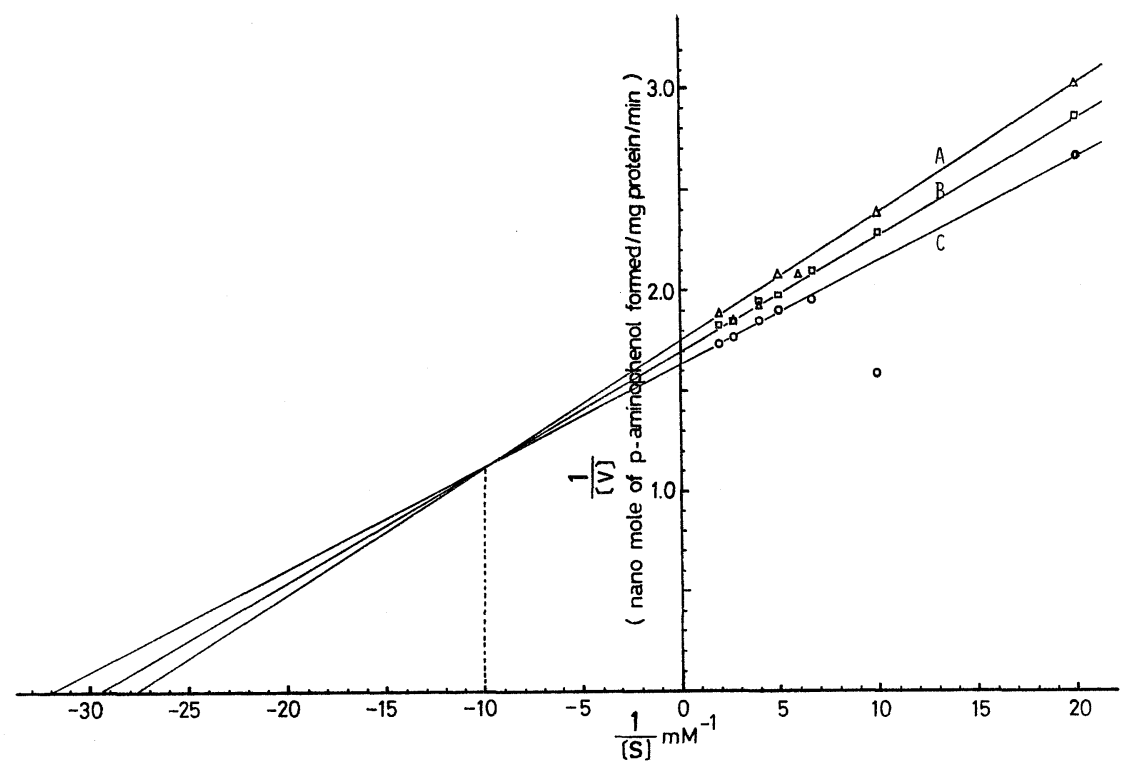

Fig. 3 Lineweaver-Burk plots showing inhibition of aniline hydroxylase by cadmium administered under in vivo conditions at doses of 0.45 (A), 0.32 (B) $\mathrm{mg} \mathrm{Cd} / \mathrm{kg}$ and the corresponding control (C) 
was $4.10 \mathrm{nmole} / \mathrm{mg}$ protein, corresponding to $57 \%$ of the control value.

On the other hand, the decrement of aniline hydroxylation activity by cadmium administration was slight as compared with aminopyrine demethylation activity as shown in Table 4.

Fig. 2 shows a Lineweaver-Burk plot of aminopyrine demethylase activity dependent cytochrome $\mathrm{P}-450$ in the microsomes. Cadmium administered to rats caused the decrease in the $V \max$ values of aminopyrine demethylase however, the $\mathrm{Km}$ value $(0.53 \mathrm{mM})$ was not changed. A Lineweaver-Burk plot for aniline hydroxylase dependent cytochrome $\mathrm{P}-450$ is given in Fig. 3. Vmax values of aniline hydroxylase from hepatic microsomes of rats administered cadmium were decreased, and $\mathrm{Km}$ values were increased corresponding to the cadmium doses. The experiment to determine if cadmium, added directly in vitro to the reaction mixture containing the hepatic microsomes isolated from untreared rats, could inhibit the metabolism of aminopyrine and aniline, was conducted. Microsomes derived from control rats were incubated with aminopyrine or aniline in the presence of cadmium in concentration of $10^{-6} \mathrm{M}$ to $10^{-3} \mathrm{M}$.

Fig. 4 shows the remaining activity of aminopyrine demethylase and aniline hydroxylase by cadmium added directly in vitro. The activity of aminopyrine demethylase was decreased linealy with the concentration of added cadmium. Whereas the activity of aniline hydroxylase was decreased sigmoidally with the concentration of added cadmium. The

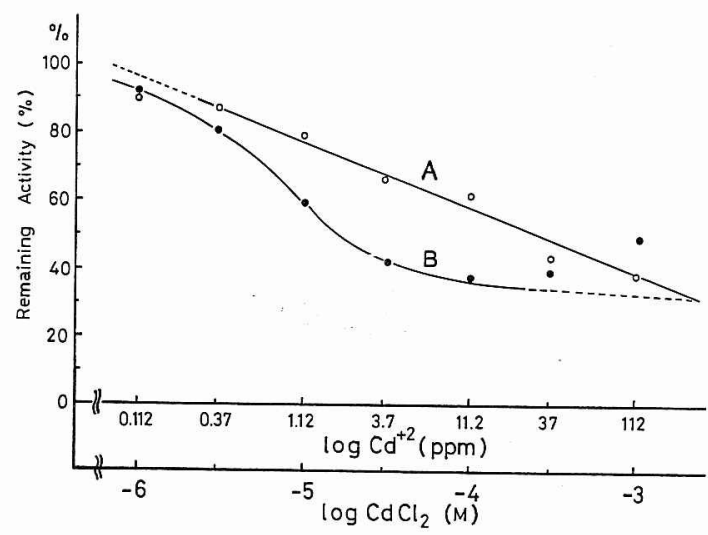

Fig. 4 The change of aminopyrine demethylase and aniline hydroxylase activity by cadmium addition in vitro system. The curve showing aminopyrine demethylase (A) and aniline hydroxylase (B). Cadmium concentrations were expressed with $\log$ scale.

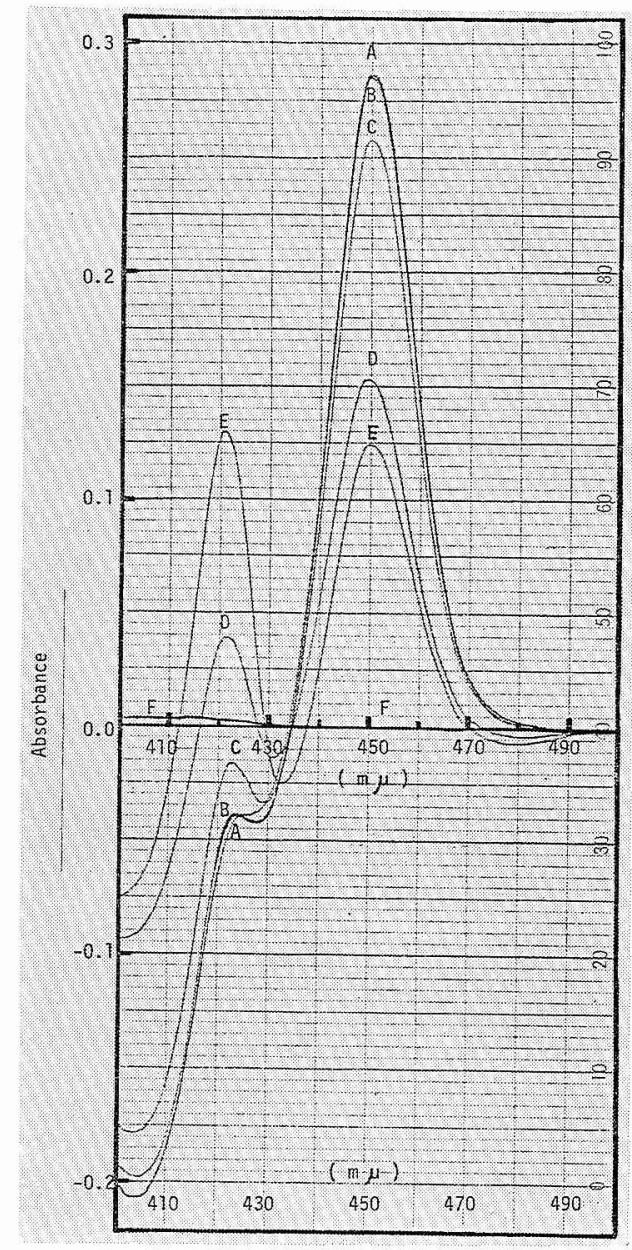

Fig. 5 The difference spectrum change of cy tochrome P-450 by cadmium addition in vitro. The specimens were incubated for $30 \mathrm{~min}$ at $37^{\circ} \mathrm{C}$ after cadmium addition and the difference spectrum measured. The curve shows control (A), $0.112 \mathrm{ppm}$ (B), $1.12 \mathrm{ppm}$ (C), $11.2 \mathrm{ppm}$ (D), 112 ppm (E) and base line (F). Protein used was $1.75 \mathrm{mg} / \mathrm{m} l$ concentrations. 
activity of aniline hydroxylase observed in the presence of $10^{-3} \mathrm{M}$ and $3 \times 10^{-3} \mathrm{M}$ of cadmium was heigher than that in $10^{-4} \mathrm{M}$ cadmium. This discrepancy may be due to the decrease of cadmium ion concentration caused by the formation of a complex between cadmium and phosphate. These results indicate that both enzymes were inhibited by cadmium added directly in vitro. In the measurement of cytochrome $\mathrm{P}-450$ in vivo, the shoulder or peak at $420 \mathrm{~nm}$ was observed. So, the change of cytochrome P-450 by cadmium added directly in vitro was determined to characterize this shoulder or peak at $420 \mathrm{~nm}$ (Fig. 5). The addition of cadmium in vitro caused the denaturation of cytochrome $\mathrm{P}-450$ to cytochrome $\mathrm{P}-420$, and the denaturation was dependent on the cadmium concentration. It was found that cadmium also caused the denaturation of cytochrome $\mathrm{P}-450$ in vivo. These results may indicate that the inhibition of aminopyrine demethylase and aniline hydroxylase by cadmium in vitro is mainly due to the denaturation of cytochrome $\mathrm{P}-450$.

\section{DISCUSSION}

Results in the present study indicate that the drug-metabolizing enzyme system is very sensitive to cadmium. The concentrations of cadmium that decreased the activity of the system shows no effect on serum glutamate oxaloacetate transferase (sGOT) and serum glutamate pyruvate transferase (sGPT) in this experiment. This indicates that this system was more sensitive to cadmium than clinical assay with serum, and that this system was excellent target to determine the toxicity of cadmium.

Stowe et al. ${ }^{13)}$, reported the morphological abnormalities of endplasmic reticulum of hepatocytes by electron microscopy without the change of the above two serum enzymes in rabbit by cadmium administration. The decrease of microsomal protein observed in this experiment (Table 1) may correspond to the decrease of endoplasmic reticulum as well as the observation by Stwoe et al. It is well known that most of the cadmium accumurated in livers is bound to metallothionein ${ }^{14)}$ in soluble supernatant fraction, and that a few cadmium also binds to some particulates fraction, i.e., microsomes, mitchondria and nuclei ${ }^{15)}$. The supernatant fraction contained about $90 \%$ of the cadmium in whole liver, and microsome fraction contained about $6 \%$. This result corresponded to the resultreported by Colucci et al. ${ }^{15)}$. It was presumed from the results of Fig. 4 and Fig. 5 that the contents of cadmium accumulated in hepatic microsomes were sufficient to destroy cytochrome P-450 and to inhibit the activity of aminopyrine demethylase and aniline hydroxylase. The contents of other metals were determined as shown in Fig. 1. Cadmium administration caused the increment of zinc and iron in livers.

It is ascertained that the source of zinc results from metallothionein mainly, and the increment of zinc in liver is dependent on the increment of metallothionein by cadmium administration, and that metallothionein play the role of detoxification of cadmium $^{1)}$. The source of iron in liver is ferritin mainly, but the significance of increasing ferritin can not be explained from this data. It was found that at least the decrease of cytochrome P-450 is not due to the deficiency of iron in liver.

On the other hand, copper content was not changed in the liver by cadmium administration.

Cadmium decreased cytochrome P-450 remarkably in the drug-metabolizing enzyme system of hepatic microsomes; cadmium decreased the cytochrome P-450 contents in vivo (Table 3). It was found that cytochrome $\mathrm{P}-450$ was changed to cytochrome $\mathrm{P}-420$ by cadmium in vitro, and that the denaturation was dependent on the concentration of cadmium as shown in Fig. 5.

It is ascertained that the denaturation of cytochrome $\mathrm{P}-450$ to cytochrome $\mathrm{P}-420$ is due to the destruction of ferric-thiol ligand in case of some mercury compounds. 
So, the decrease of cytochrome P-450 contents by cadmium administration may be also due to the evidence that cadmium destroied ferric-thiol ligand of cytochrome $\mathrm{P}-450$ in hepatic microsomes. Cadmium also caused the decrease of cytochrome $b_{5}$ contents, but the decrease ratio was less than that of cytochrome P-450.

Recently, Levin and Kuntzman ${ }^{16)}$ reported that the turnover rate of cytochrome P-450 was $48 \mathrm{hr}$. in its slow phase, and that it was faster than that of cytochrome $b_{5}$.

The difference between cytochrome P-450 and cytochrome $b_{5}$ content by cadmium administration may be reflecting to the difference in the turnover rate of the two cytochromes because cadmium causes not only the destraction of cytochrome, but the inhibition in hem synthesis of cytochromes. Cadmium caused in vivo the decrease in specific activity of aminopyrine demethylase and aniline hydroxylase dependent cytochrome P-450. The former was decreased more than the latter as shown in Table 4.

These results indicate that the sensitivity of aminopyrine demethylase and aniline hydroxylase to cadmium is different. On the other hand, it was found that aniline hydroxylase was more sensitive to cadmium than aminopyrine demethylase in vitro as shown in Fig. 4. The sentitivity of the two enzymes to cadmium is reversed in vivo and in vitro. The effect of cadmium on the active site of aminopyrine demethylase and aniline hydroxylase dependent cytochrome P-450 was evaluated from Lineweaver-Burk plot in vivo. In the aminopyrine demethylase assay, Vmax values were changed in correlation to cadmium doses, and no difference in $\mathrm{Km}$ value was observed.

This observation may indicate the possibility that cadmium had no effect on the active site of cytochrome P-450 regarding aminopyrine demethylation reaction, and caused only the decrease of cytochrome P-450.

Lineweaver-Burk plot of aniline hydroxylase demonstrated the increase in $\mathrm{Km}$ values and the decrease in Vmax values in correlation to cadmium doses, respectively.

This may indicate the possibility that cadmium had some effect on the active site of aniline hydroxylase dependent cytochrome P-450, and caused also the destraction of cytochrome $\mathrm{P}-450$ in rat liver. These results may indicate that the decrease of the drug-metabolizing enzyme activity is mainly due to the decrease of cytochrome $\mathrm{P}-450$ rather than the inhibition of the terminal oxidase by cadmium.

This explanation was also supported by the decrease of microsomal protein and the denaturation of cytochrome $\mathrm{P}-450$ by cadmium because the decrement ratio of cytochrome $\mathrm{P}-450$ corresponded to the decrease ratio of microsomal protein.

Acknowledgment: The authors gratefully acknowledge Dr. Yuzo Yoshida, a assistant professor in Mukogawa Women's University, for his useful advice, and wish to thank to Mrs Phyllis Ogawa for revision of manuscript in Enlish.

\section{REFERENCES}

1) Friberg, L., Piscator, M., Nordberg, G. F. and Kjellström, T.: Cadmium in the Environment (Second ed.) C. R. C. press Cleveland (1974).

2) Berlin, M. and Ullberg, S.: The fate of $\mathrm{Cd}^{109}$ in the mouse, An autoradiographic study after a single intravenous injection of $\mathrm{Cd}^{109} \mathrm{Cl}_{2}$, Arch. Environ. Health., 7, 686-693 (1963).

3) Caujolle, F., Oustin, J. \& Silve-Mamy, G.: Fixation et circulation enterohepatique de cadmium, Europ. J. Toxicol., 4, 310-315 (1971).

4) Gillette, J. R.: Factors that affect the stimulation of the microsomal drug enzymes induced by foreign compounds, Advance in Enzyme Regulation: 1, 215-223, Pergamon Press (1963).

5) Konat, G. and Clausen, J.: The activity of cytochrome P-450 complex in multiple intoxication of the 
mouse, Environ. Physiol., 1, 72-78 (1971).

6) Unger, M. and Clausen, J.: Liver cytochrome P-450 activity after intraperitoneal administration of cadmium salts in the mouse, Environ. Physiol. Biochem., 3, 236-242 (1973).

7) Pence, D. H., Miya, T. S. and Schnell, R. C.: Cadmium alteration of Hexobarbital action: Sex-related differences in the rat, Toxicol, Appl. Pharmacol., 39, 89-96 (1977).

8) Omura, T. and Sato, R.: The carbon monoxide binding pigment of liver microsomes, I. Evidence for its hemoprotein nature, J. Biol. Chem., 239, 2370-2377 (1964).

9) Nash, T.: The colorimetric estimation of formaldehyde by means of Hantzsch reaction, Biochem. J., 55, 416-421 (1953).

10) Imai, Y., Ito, A. and Sato, R.: Evidence for biochemically different types of vesiceles in the hepatic microsomal fraction, J. Biochem. (Tokyo), 60, 417-428 (1966).

11) Lowry, O. H., Rosebrough, N. J., Farr, A. L. and Randall, R. J.: Protein measurement with the Folin phenol reagent, J. Biol. Chem., 193, 265-275 (1951).

12) Geldmacher v. Mallinckrodt, M. and Pooth, M.: Gleichzeitige spektrographische Prüfung auf 25 Mettalle und Metalloide in biologischen Material, Arch. Toxik., 25, 5-18 (1969).

13) Stowe, H. D., Wilson, M. and Goyer, R. A.: Clinical and Morphologic effects of oral cadmium toxicity in rabbits, Arch. Pathol., 94, 389-405 (1973).

14) Kägi, J. H. R. and Vallee, B. L.: Metallothionein: A cadmium -and zinc-containing protein from eqine renal cortex, J. Biol. Chem., 236, 2435-2441 (1961).

15) Colucci, A. V., Winge, D. and Krasno, J.: Cadmium accumulation in rat liver, Arch. Environ. Health., 30, 153-157 (1975).

16) Levin, W. and Kuntzman, R.: Biphasic decrease of radioactive hemoprotein from liver microsomal carbon monoxide-binding particles, Effect of 3-methyl-cholanthrene, J. Biol. Chem., 244, 3671-3676 (1969).

\title{
ラット肝蔵における薬物代謝酵素系に対するカドミウムの影響
}

\author{
嵯峨井＼cjkstart勝・白石不二雄・久保田憲太郎
}

\section{国立公害研究所}

ラットに低濃度の塩化カドミウムを頻回, 腹腔内投与しその肝臓の薬物代謝酵素系に対する影響を調べた。こ の時血清学的肝機能検查での異常はなかった。このような条件下であカドミウムはミクロソーム画分を減少させ, 更に薬物代謝酵素系の中心をなしているチトクロームP-450 含量の減少をひき起した。

一方, チトクローム $b_{5}$ あ減少したがチトクローム P-450 の減少に比べると極めて少なかった。このチトクロ 一ム P-450 の減少は in vitro の実験でチトクロームP-420への変化が観察されたととから, その変性・破壊に よるあのかむしれない。又チトクロームP-450のターミナルオキシダーゼ活性に対するカドミウムの影響をアミ ノピリンとアニリンを基質として in vivo と in vitro で調べた。in vivo でアミノピリン脱メチル化活性はアニ リン水酸化活性よりも低下しており in vitro とは逆の結果を示した。

その他の結果をむ含めると，カドミウムは肝臓の薬物代謝機能の低下をひき起すが，てれはカドミウムがミク ロソーム画分を破壊し，特にそのチトクロームP-450 の破壞を主としているてとがわかった。

（受付 1977年 4 月11日） 